\title{
In vitro protoscolicidal efficacy appraisal of methanolic herbal extracts against hydatid cysts
}

\author{
Aman D. Moudgil ${ }^{1 *}$, Pallavi Moudgil ${ }^{2}$, Dinesh Sharma ${ }^{3}$, Prashant S. Daundkar ${ }^{3}$, \\ and R. K. Agnihotri ${ }^{1}$ \\ ${ }^{1}$ Department of Veterinary Parasitology, DGCN College of Veterinary and Animal Sciences, CSK Himachal Pradesh \\ Krishi Vishvavidyalaya, Palampur (H.P.), India \\ ${ }^{2}$ Department of Veterinary Public Health and Epidemiology, College of Veterinary Sciences, LUVAS, Hisar \\ (Haryana), India \\ ${ }^{3}$ Department of Veterinary Pharmacology, DGCN College of Veterinary and Animal Sciences, CSK Himachal \\ Pradesh Krishi Vishvavidyalaya, Palampur (H.P.), India
}

\begin{abstract}
MOUDGIL, A. D., P. MOUDGIL, D. SHARMA, P. S. DAUNDKAR, R. K. AGNIHOTRI: In vitro protoscolicidal efficacy appraisal of methanolic herbal extracts against hydatid cysts. Vet. arhiv 90, 197-204, 2020.
\end{abstract}

\section{ABSTRACT}

The present study aimed at an evaluation of the protoscolicidal potential of methanolic extracts of three herbs; Ferula asafoetida (dried latex), Trachyspermum ammi (fruits) and Hippophae salicifolia (leaves) at three different concentrations $(10,20$ and $30 \mathrm{mg} / \mathrm{mL})$ for 20,40 and 60 minute treatment intervals, with respect to standard allopathic drug albendazole. The in-vitro viability of the protoscolices was assessed by the Eosin exclusion method. The slope of mortality and lethal concentration for $50 \%\left(\mathrm{LC}_{50}\right)$ was determined from the regression graphs of the probit mortality of protoscolices plotted against log values of increasing concentrations of herbal extracts for 60 minute treatment intervals. The percentage of mortality caused by various extracts at concentrations ranging from $10-30 \mathrm{mg} / \mathrm{mL}$ varied from $29.54-97.76 \%$ with maximum mortality of $97.76,97.30$ and $81.91 \%$ recorded with methanolic extracts of $F$. asafoetida, T. ammi and H. salicifolia, respectively. Among all the extracts, the highest protoscolicidal activity was exhibited by F. asafoetida at 20 and $30 \mathrm{mg} / \mathrm{mL}$ concentrations in the $60(97.16 \%)$ and $40 / 60$ minutes $(97.20 \%$ and $97.76 \%$ ) treatments, respectively, and it showed a minimum $\mathrm{LC}_{50}$ value of 0.204 , followed by $T$. ammi at 0.933 . As compared to the standard allopathic drug, albendazole, the methanolic extracts of F. asafoetida and T. ammi exhibited better or comparable protoscolicidal activities.

Key words: cystic echinococcosis; herbs; lethal concentration; protoscolicidal activity

\section{Introduction}

Cystic echinococcosis is a severe, chronic, zoonotic disease distributed worldwide with immense public health significance (PENSEL et al., 2014). The site of predilection of adult tapeworms Echinococcus granulosus is the intestines of carnivores, most commonly dogs and other wild canids (GHOLAMI et al., 2013); whereas, the metacestodal larval stages establish themselves in a wide range of intermediate hosts, including sheep, goat, cattle, pigs, horses and humans (BUDKE et

\footnotetext{
*Corresponding author:

Dr. Aman Dev Moudgil, Department of Veterinary Parasitology, DGCN COVAS, CSK HPKV, Palampur (H.P.) 176062, Phone: +91 941 887 7547; E-mail: moudgil.aman@gmail.com
} 
al., 2009). The intermediate hosts are infected by consumption of the eggs of the tapeworm with contaminated feed and water (MOAZENI et al., 2017). The blood circulation helps in dissemination of the liberated embryos (in the intestines) to the vital organs, including the lungs, liver etc., where hydatid cysts develop (MOAZENI et al., 2017). The life cycle completes when the definitive hosts (dogs and wild canids) are infected by consumption of infected viscera with fertile hydatid cysts (LARRIEU et al., 2001). The patient is subjected to surgery or different therapeutic treatments based upon the size, location and number of the hydatid cysts (NICOLAO et al., 2014).

Surgery is the preferred method for removal of intact hydatid cysts (GHOLAMI et al., 2013) but certain complications are associated with the technique, i.e. intra-operative spillage of protoscolices, leading to anaphylactic shock and reoccurrence, or multiple secondary infections (echinococcosis) (MORO and SCHANTZ, 2009). Various protoscolicidal agents, such as formalin, alcohol, hypertonic saline and povidone iodine, have been used in the past (KARAOGLANOGLU et al., 2011) but most of these agents have led to toxicity and severe hepato-billiary complications, along with fatal hyperthermia (ADAS et al., 2009; KARAOGLANOGLU et al., 2011). In inoperable cases, the only alternative remains chemotherapy using benzimidazole-methylcarbamate (BZ) compounds, such as albendazole (ABZ) and mebendazole. The application of BZ drugs cures approximately one-third of the patients, whereas regression of hydatid cysts has been recorded in $30-50 \%$ cases. On the other hand, $20-40 \%$ cases do not respond to the therapy (WALKER et al., 2004). Moreover, long term chemotherapy with BZ compounds has also led to certain adverse reactions in patients, including gastrointestinal disturbances, vomiting, eosinophilia, alopecia, leukopenia, elevation in transaminase levels and, most importantly, parasitic resistance (HEMPHILL and MULLER, 2009).

Considering the adverse side effects associated with surgery and chemotherapy, the search for new therapeutic alternatives with the least adverse effects and high efficacy (such as the use of traditional medicinal plants) has increased.
Ferula asafoetida is known to have promising anthelmintic, antibiotic, antimicrobial, antifungal, anticancer, anti-diabetic and therapeutic properties due to the presence of polyphenolic compounds, such as terpenoids, sulphide derivatives, phenols and minerals (GUNDAMARAJU, 2013). Also, Trachyspermum ammi, a member of Apiaceae family, consists of $2-4 \%$ essential oils rich in monoterpes, such as thymol, $\gamma$-terpinene, $p$-cymene and is known to have anthelmintic, insecticidal and antiseptic properties (MOAZENI et al., 2012). Hippophae salicifolia contains tocopherols, sterols, flavinoids, carotenoids, lipids, ascorbic acid and tannins, and eventually exhibits biological and therapeutic properties, including anti-oxidant, antitumour, hepatoprotective and anti-inflammatory activities (SAIKIA and HANDIQUE, 2013). Hence, the present study was envisaged with the aim of identifying new protoscolicidal phyto-agents for the successful treatment of hydatidosis.

\section{Materials and methods}

Collection of protoscolices. The hydtid cysts were collected aseptically from the liver and lungs of infected sheep and goats, slaughtered in and around Palampur, Himachal Pradesh (NorthWestern Himalayan region), India. The intact cysts were then transferred (at $4^{\circ} \mathrm{C}$ in ice box) to the Department of Veterinary Parasitology, DGCN College of Veterinary and Animal Sciences, Palampur (H.P.), India. The cysts were thoroughly cleaned with $0.9 \%$ phosphate buffered saline $(\mathrm{pH}$ 7.2). A small quantity of cyst fluid was aspirated (from all the cysts) with a syringe $(10 \mathrm{~mL})$, and was subjected for assessment of fertility. In the case of fertile cysts, the entire amount of cystic fluid was then aspirated and transferred into a beaker and left as such for 2 hours, in order to allow the protoscolices to settle down. The supernatant was then removed and the settled protoscolices were then washed 5 times with normal saline. The protoscolices were then counted under a microscope by taking a drop of the sediment on a microscopic slide. The viability status of the protoscolices was assessed with the Eosin exclusion method (SHAHNAZI et al., 2016). The cysts/ cystic fluid exhibiting more than $90 \%$ viability were considered for further experiments (SMYTH and BARRETT, 1980). 
Procurement of plant material and methanolic extract preparation. Ferula asafoetida (dried latex) and Trachyspermum ammi (fruits) were procured from a local market, whereas the leaves of Hippophae salicifolia were procured from Kukumseri (Lahaul and Spiti) of Himachal Pradesh. The collected leaves were shade dried, and ground to obtain fine powder. Similarly, the fruits of $T$. ammi were also processed to obtain a fine powder. Fifty grams of powdered material for all species were weighed and mixed with $400 \mathrm{~mL}$ of absolute methanol (Analytical Reagent, Ranbaxy Laboratory Limited, S.A.S Nagar, Punjab, India) separately, and left for 24 hours in a $500 \mathrm{~mL}$ conical flask. The flasks were shaken at small intervals at room temperature and then placed in an electric tissue bath at a temperature of $40^{\circ} \mathrm{C}$. The content was then filtered through triple Whatman filter paper no. 1, and the filtrate was subsequently dried in a crucible in an electric tissue float bath. After extracting the dried filtrate, it was lyophilized and stored at $4^{\circ} \mathrm{C}$ until further use.

In vitro protoscolicidal efficacy. In the present study, three different concentrations $(10,20$ and $30 \mathrm{mg} / \mathrm{mL}$ ) of each herb i.e. F. asafoetida, T. ammi and $H$. salicifolia was evaluated at 20, 40 and 60 minutes treatment intervals with respect to the standard allopathic drug albendazole, following the protocol of SHAHNAZI et al. (2016). Different concentrations were prepared by adding the required 10, 20 and $30 \mathrm{mg}$ of lyophilized methanolic extracts per $\mathrm{mL}$ of normal saline (SHAHNAZI et al., 2016). Then, in each evaluation test tube, $2.5 \mathrm{~mL}$ of herbal concentration was added to $100 \mathrm{~mL}$ of cystic fluid containing around 1000 protoscolices, for periods of 20,40 and 60 minutes at $37^{\circ} \mathrm{C}$. Following incubation, $10 \mathrm{~mL}$ normal saline was added to each tube and centrifuged for $1 \mathrm{~min}$. at $3000 \mathrm{rpm}$. After removal of the supernatant, $0.1 \%$ aqueous eosin was added to the sediment and mixed gently. The supernatant was again removed after incubation for around 10-15 min. The sediment was then observed under a light microscope. The stained (dead) and unstained (live) protoscolices were then counted to evaluate the live and dead percentage, as well as mortality rate. Along with the test concentrations, a negative control group (containing $0.9 \%$ PBS) was also included to assure the accuracy of the test and for quality control. The test containing protoscolices treated with albendazole $(10 \mu \mathrm{g} /$ $\mathrm{mL}$ ) was considered as the positive control. All the experiments were performed in triplicate (DALIMI et al., 2002).

Statistical analyses. Dose response data were analysed by the probit method (FINNEY, 1962) using GraphPad Prism 7 software. The slope of mortality and lethal concentration for $50 \%\left(\mathrm{LC}_{50}\right)$ was determined from the regression graphs of probit mortality of protoscolices plotted against log values of increasing concentrations of herbal extracts for 60 minute treatment intervals.

\section{Results and discussion}

The present study is an effort to compare the efficacies of different herbal extracts used earlier (T. ammi) with newer ones ( $F$. asafoetida and $H$. salicifolia) with respect to their lethal concentration $\left(\mathrm{LC}_{50}\right)$ values against $E$. granulosus protoscolices. Data on the slope [95\% confidence limit (CL)], goodness of fit $\left(R^{2}\right)$ and $\mathrm{LC}_{50}$ were determined at different concentrations for different time intervals and the results are presented in Table 1. The regression graph of the mean mortality of protoscolices plotted against the log values of progressively increasing concentrations of methanolic herbal extracts of $F$. asafoetida, T. ammi and H. salicifolia is shown in Figs 1-3, respectively.

Table 1. Dose response data of protoscolices against various herbal extracts at a 60 minute treatment interval

\begin{tabular}{|l|c|c|c|}
\hline Herbal extract & Slope \pm SE $(95 \%$ CL) & $R^{2}$ & LC $_{50}$ \\
\hline Ferula asafoetida & $5.62 \pm 0.44(-0.03$ to 11.28$)$ & 0.86 & 0.204 \\
\hline Trachyspermum ammi & $5.04 \pm 0.54(-1.79$ to 11.88$)$ & 0.88 & 0.933 \\
\hline Hippophae salicifolia & $2.52 \pm 0.29(-1.25$ to 6.30$)$ & 0.98 & 12.02 \\
\hline
\end{tabular}




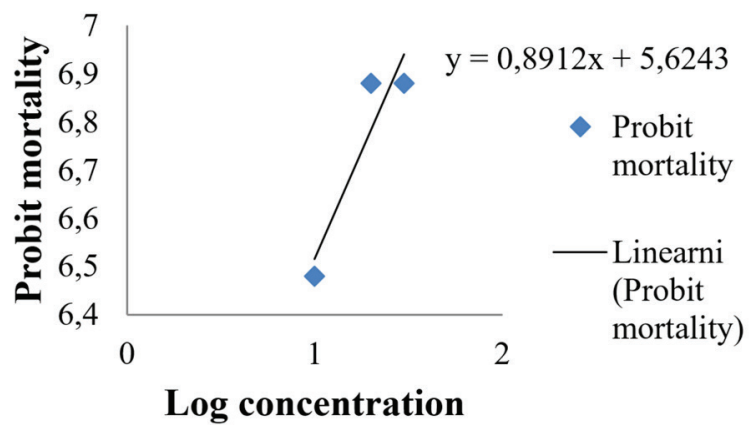

Fig. 1. Dose mortality curve of protoscolices against different concentrations of methanolic extracts of Ferula asafoetida

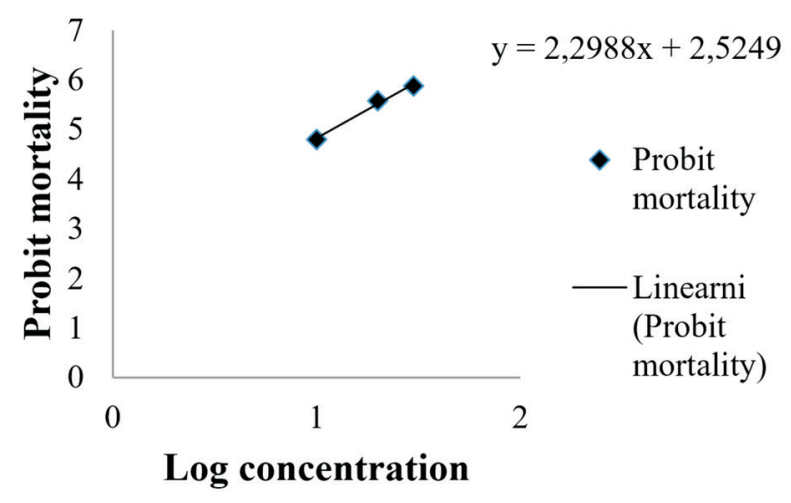

Fig. 2. Dose mortality curve of protoscolices against different concentrations of methanolic extracts of Trachyspermum ammi

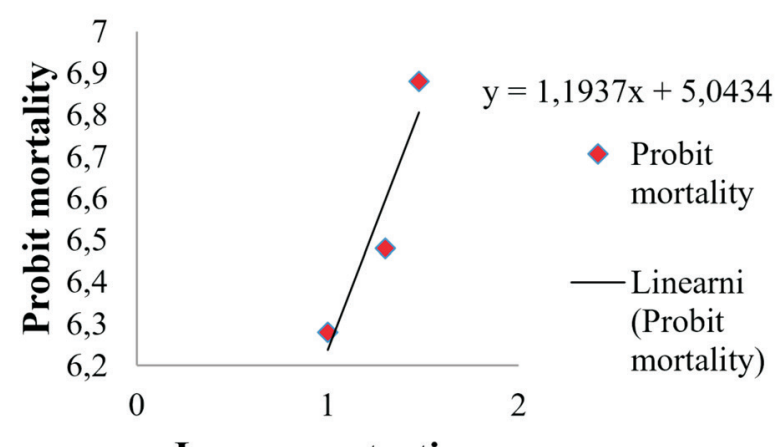

Log concentration

Fig. 3. Dose mortality curve of protoscolices against different concentrations of methanolic extracts of Hippophae salicifolia

From the regression equation, the $\mathrm{LC}_{50}$ values of $F$. asafoetida, T. ammi and H. salicifolia were calculated as $0.204,0.933$ and 12.02 , respectively. The results indicated the minimum $\mathrm{LC}_{50}$ values for $F$. asafoetida and comparatively higher values for $H$. salicifolia. The lower $\mathrm{LC}_{50}$ values for $F$. asafoetida gum resin could easily be associated with its properties as an expectorant, laxative and vermifuge agent (MAHENDRA and BISHT, 2012). The anthelmintic activity of $F$. asafoetida could be implicated in the presence of polyphenolic compounds, which could have led to uncoupling of oxidative phosphorylation in the targeted parasites (GUNDAMARAJU, 2013). The protoscolicidal property of $T$. ammi could be associated with the presence of thymol (ROSTAMI et al., 2016), $\gamma$-terpinene, p-cymene (MOAZENI et al., 2012). The possible mechanism for thymol action could be asserted as the potentiation of ATPase activity, resulting in interference with the energy metabolism of parasites (ROSTAMI et al., 2016). The amphipathic and hydrophobic behaviour of thymol and p-cymene also results in alteration of the membrane permeability and leakage of intracellular material (MOAZENI et al., 2012). The results of the present study indicated the higher potential of methanolic extract of $F$. asafoetida as a protoscolicidal agent.

The efficacy of the herbal extracts can also be appreciated by observation of the collapsed germinal layers of the dead protoscolices with escaped materials (Fig. 4). However, the germinal layers of the live protoscolices were turgid and undamaged (Fig. 5). The negative control group (containing $0.9 \%$ PBS) of protoscolices, when examined at the initiation of the trial, showed turgidity and were motile. Only a few protoscolices were found damaged. The eosin exclusion method revealed $0.56-1.56 \%$ mortality rate. The mortality percentage caused by the different extracts at concentrations ranging from $10-30 \mathrm{mg} / \mathrm{mL}$ varied from $29.54-97.76 \%$ with maximum mortality of $97.76,97.30$ and $81.91 \%$ recorded against methanolic extracts of $F$. asafoetida, T. ammi and H. salicifolia, respectively (Table 2). F. asafoetida proved to be the most effective herbal extract, and depicted the highest protoscolicidal activity at 20 and $30 \mathrm{mg} / \mathrm{mL}$ concentrations for the $60(97.16 \%)$ and $40 / 60$ minute $(97.20 \& 97.76 \%)$ treatments, respectively. 


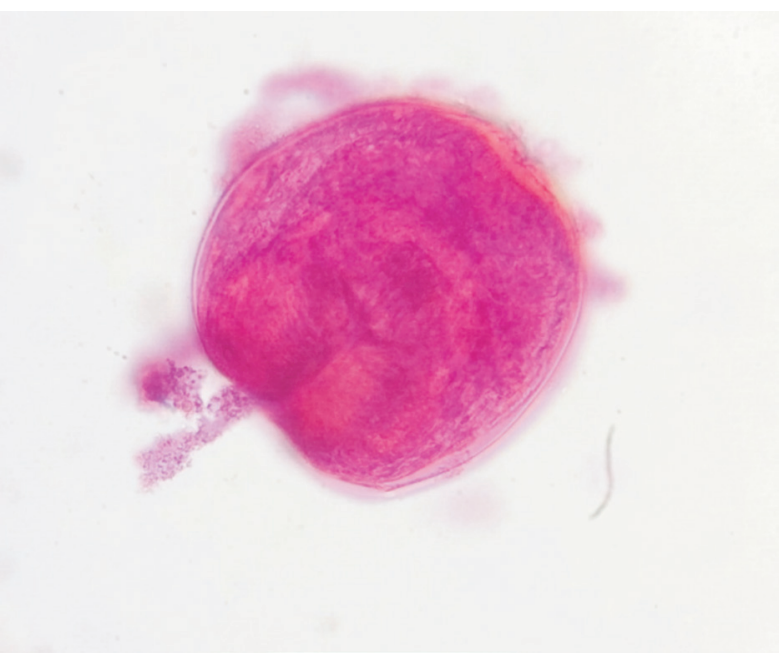

Fig. 4. Dead protoscolex after exposure to the herbal extract exhibiting damaged germinal membrane

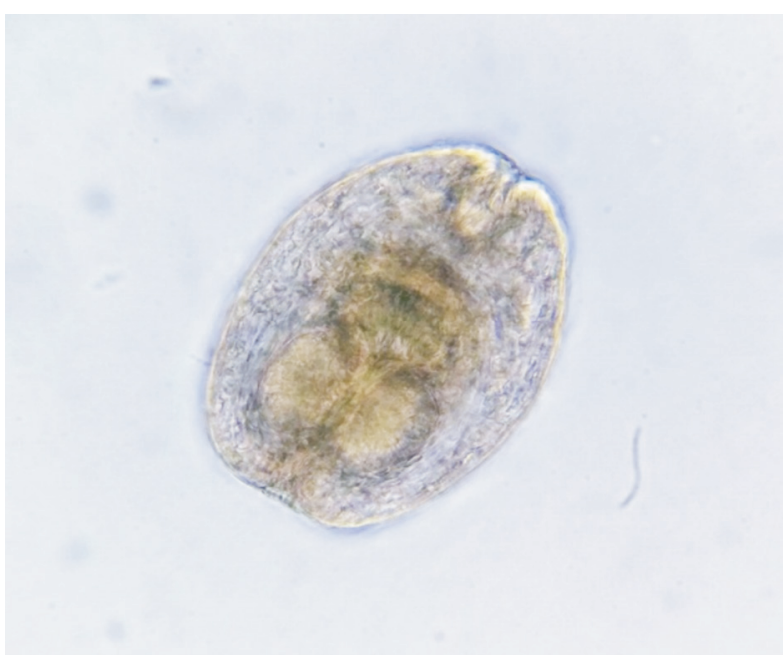

Fig. 5. Live protoscolex after exposure to the extract

Table 2. Protoscolicidal efficacies of various herbal extracts at various exposure intervals

\begin{tabular}{|c|c|c|c|c|c|}
\hline Concentration & $\begin{array}{l}\text { Exposure time } \\
\text { (minutes) }\end{array}$ & $\begin{array}{l}\text { Total protoscolices } \\
(\text { Mean } \pm \text { SD })\end{array}$ & $\begin{array}{l}\text { Live protoscolices } \\
\quad(\text { Mean } \pm \text { SD })\end{array}$ & $\begin{array}{l}\text { Dead protoscolices } \\
(\text { Mean } \pm \text { SD })\end{array}$ & $\begin{array}{c}\text { Mortality rate } \\
(\%)\end{array}$ \\
\hline \multirow{3}{*}{$0.9 \% \mathrm{PBS}$} & 20 & $412 \pm 20.88$ & $409.67 \pm 19.39$ & $2.33 \pm 1.57$ & 0.56 \\
\hline & 40 & $361.33 \pm 34.19$ & $356.67 \pm 31.89$ & $4.67 \pm 2.30$ & 1.29 \\
\hline & 60 & $363.67 \pm 43.66$ & $358 \pm 42.33$ & $5.67 \pm 1.53$ & 1.56 \\
\hline \multirow{3}{*}{ Albendazole } & 20 & $377 \pm 52.16$ & $49 \pm 12$ & $328 \pm 51.12$ & 87 \\
\hline & 40 & $342 \pm 39.95$ & $29 \pm 11.79$ & $313 \pm 50.16$ & 91.52 \\
\hline & 60 & $353.67 \pm 85.41$ & $12.33 \pm 3.51$ & $341.33 \pm 88.46$ & 96.51 \\
\hline \multirow{3}{*}{$\begin{array}{l}\text { FAM1 } \\
(10 \mathrm{mg} / \mathrm{mL})\end{array}$} & 20 & $382.33 \pm 26.08$ & $101 \pm 23.64$ & $281.33 \pm 25.48$ & 73.58 \\
\hline & 40 & $367.66 \pm 61.23$ & $68.33 \pm 4.04$ & $306 \pm 49.79$ & 83.23 \\
\hline & 60 & $370.66 \pm 25.79$ & $23.33 \pm 6.50$ & $347.33 \pm 32.19$ & 93.70 \\
\hline \multirow{3}{*}{$\begin{array}{l}\text { FAM2 } \\
(20 \mathrm{mg} / \mathrm{mL})\end{array}$} & 20 & $379.33 \pm 59.77$ & $86.67 \pm 9.29$ & $292.66 \pm 67.85$ & 77.15 \\
\hline & 40 & $378.33 \pm 69.61$ & $46 \pm 9.64$ & $332.33 \pm 63.70$ & 87.84 \\
\hline & 60 & $329 \pm 17$ & $9.33 \pm 4.04$ & $319.67 \pm 17.47$ & 97.16 \\
\hline \multirow{3}{*}{$\begin{array}{l}\text { FAM3 } \\
(30 \mathrm{mg} / \mathrm{mL})\end{array}$} & 20 & $350 \pm 51.64$ & $65.67 \pm 12.58$ & $284.33 \pm 49.90$ & 81.23 \\
\hline & 40 & $333.33 \pm 39.51$ & $9.33 \pm 2.51$ & $324 \pm 38.97$ & 97.20 \\
\hline & 60 & $372 \pm 49.73$ & $8.33 \pm 2.08$ & $363.67 \pm 50.84$ & 97.76 \\
\hline \multirow{3}{*}{$\begin{array}{l}\text { TAM1 } \\
(10 \mathrm{mg} / \mathrm{mL})\end{array}$} & 20 & $353 \pm 27.62$ & $98 \pm 12.12$ & $255 \pm 24.57$ & 72.24 \\
\hline & 40 & $364.67 \pm 42.72$ & $74.67 \pm 8.73$ & $290 \pm 34.07$ & 79.52 \\
\hline & 60 & $403 \pm 23.81$ & $38.33 \pm 4.04$ & $364.67 \pm 23.96$ & 90.49 \\
\hline \multirow{3}{*}{$\begin{array}{l}\text { TAM2 } \\
(20 \mathrm{mg} / \mathrm{mL})\end{array}$} & 20 & $375.67 \pm 33.50$ & $82.33 \pm 10.59$ & $293.33 \pm 28.18$ & 78.08 \\
\hline & 40 & $361.67 \pm 37.68$ & $44.67 \pm 10.26$ & $307 \pm 32.51$ & 87.29 \\
\hline & 60 & $333 \pm 51.39$ & $21 \pm 8$ & $312 \pm 58.79$ & 93.69 \\
\hline
\end{tabular}

*PBS - Phosphate Buffer saline, FAM- Ferula asafoetida methanolic extract, TAM - Trachyspermum ammi methanolic extract and HSM - Hippophae salicifolia methanolic extract 
A. D. Moudgil et al.: In vitro protoscolicidal efficacy appraisal of methanolic herbal extracts against hydatid cysts

Table 2. Protoscolicidal efficacies of various herbal extracts at various exposure intervals (continued)

\begin{tabular}{|c|c|c|c|c|c|}
\hline Concentration & $\begin{array}{l}\text { Exposure time } \\
\text { (minutes) }\end{array}$ & $\begin{array}{l}\text { Total protoscolices } \\
\quad(\text { Mean } \pm \text { SD })\end{array}$ & $\begin{array}{l}\text { Live protoscolices } \\
(\text { Mean } \pm \text { SD })\end{array}$ & $\begin{array}{c}\text { Dead protoscolices } \\
(\text { Mean } \pm \text { SD })\end{array}$ & $\begin{array}{l}\text { Mortality rate } \\
(\%)\end{array}$ \\
\hline \multirow{3}{*}{$\begin{array}{l}\text { TAM3 } \\
(30 \mathrm{mg} / \mathrm{mL})\end{array}$} & 20 & $258.33 \pm 48.54$ & $77.67 \pm 7.09$ & $180.66 \pm 55.59$ & 69.93 \\
\hline & 40 & $345.33 \pm 43$ & $23.33 \pm 5.13$ & $322 \pm 43.71$ & 93.24 \\
\hline & 60 & $346 \pm 41.07$ & $9.33 \pm 2.08$ & $336.67 \pm 43.33$ & 97.30 \\
\hline \multirow{3}{*}{$\begin{array}{l}\text { HSM1 } \\
(10 \mathrm{mg} / \mathrm{mL})\end{array}$} & 20 & $343 \pm 54.83$ & $241.67 \pm 43.43$ & $101.33 \pm 41.04$ & 29.54 \\
\hline & 40 & $404.33 \pm 11.23$ & $242.67 \pm 44.76$ & $161.66 \pm 34.42$ & 39.98 \\
\hline & 60 & $317.33 \pm 4.72$ & $182.67 \pm 12.74$ & $134.66 \pm 16.07$ & 42.43 \\
\hline \multirow{3}{*}{$\begin{array}{l}\text { HSM2 } \\
(20 \mathrm{mg} / \mathrm{mL})\end{array}$} & 20 & $381 \pm 28.51$ & $181.33 \pm 30.67$ & $199.67 \pm 37.11$ & 52.40 \\
\hline & 40 & $392.66 \pm 19.21$ & $156.33 \pm 23.67$ & $236.33 \pm 6.35$ & 60.18 \\
\hline & 60 & $332 \pm 17.69$ & $90 \pm 20$ & $242 \pm 23.89$ & 72.89 \\
\hline \multirow{3}{*}{$\begin{array}{l}\text { HSM3 } \\
(30 \mathrm{mg} / \mathrm{mL})\end{array}$} & 20 & $380.66 \pm 55.24$ & $125.66 \pm 26.67$ & $255 \pm 65.19$ & 66.98 \\
\hline & 40 & $341.33 \pm 49.09$ & $100.67 \pm 19.33$ & $240.66 \pm 52.16$ & 70.50 \\
\hline & 60 & $372.33 \pm 22.18$ & $67.33 \pm 16.67$ & $305 \pm 14.73$ & 81.91 \\
\hline
\end{tabular}

*PBS- Phosphate Buffer saline, FAM- Ferula asafoetida methanolic extract, TAM- Trachyspermum ammi methanolic extract and HSM- Hippophae salicifolia methanolic extract

On the other hand, albendazole exhibited mortality rates of $87-96.51 \%$ at different concentrations. T. ammi and $H$. salicifolia evinced 72.24-97.30 and $29.54-81.91 \%$ mortality rates at different concentrations, respectively. The observations of the present study pertaining to the efficacy of $T$. ammi are approximately in line with the findings of MOAZENI et al. (2012), who observed a $100 \%$ scolicidal effect of essential oils of $T$. ammi. The protoscolicidal efficacy of T. ammi could be ascribed to its thymol contents $(50.07 \%)$ (MOAZENI et al., 2012), which hold antibacterial (GOUDARZI et al., 2011), insecticidal (PANDEY et al., 2009) and anti-fungal (NAGALAKSHMI et al., 2000) properties. Other herbal compounds (Zataria multiflora) with high thymol contents also exhibited scolidicidal activities with mortality rates as high as $100 \%$ in past studies (MOAZENI et al., 2017). On the other hand, the exact mechanism behind the higher efficacy of $F$. asafoetida is not known; however, essential oils of different Ferula species have been observed to exhibit cytotoxic effects against human tumour cell lines (MOLLAZADEH et al., 2010; MAZZIO and SOLIMAN, 2011). F. asafoetida has also been proved to hold significant anthelmintic (GUNDAMARAJU, 2013); antileishmanial and antiparasitic properties (BAFGAHI et al., 2014). These observations could be reckoned to be associated with the presence of polyphenolic (tannins) and disulphide compounds in F. asafoetida.

\section{Conclusions}

As compared to the standard allopathic drug, albendazole, the methanolic extracts of $F$. asafoetida and $T$. ammi exhibited better or comparable protoscolicidal activities. Being phyto-agents, the herbs manifest no side effects and could easily be chosen as a replacement for allopathic drugs. Further detailed studies (especially in vivo studies and stability studies inside the cysts) pertaining to these herbs against cystic echinococcosis are warranted.

\section{Conflict of interest}

Authors declare that they have no conflict of interest

\section{Acknowledgements}

The authors are thankful to the Dean, Dr. G. C. Negi College of Veterinary and Animal Sciences for providing the necessary facilities to carry out the research work. 


\section{References}

ADAS, G., S. ARIKAN, O. KEMIK, A. ONER, N. SAHIP, O. KARATEPE (2009): Use of albendazole sulfoxide, albendazole sulfone, and combined solutions as scolicidal agents on hydatid cysts (in vitro study). World J. Gastroenterol. 15, 112-116.

DOI: $10.3748 /$ wjg. 15.112

BAFGAHI, A. F., S. M. BAGHERI, S. H. HEJAZIAN (2014): Antileishmanial activity of Ferula assa-foetida oleo gum resin against Leishmania major. An in vitro study. J. Ayurveda. Integr. Med. 5, 223-226.

DOI: $10.4103 / 0975-9476.146567$

BUDKE, C. M., A. C. WHITE, H. H. GARCIA (2009): Zoonotic larval cestode infections: Neglected, neglected tropical diseases? PLoS Negl. Trop. Dis. 3, e319.

DOI: 10. 1371/journal. pntd. 0000319

DALIMI, G., M. MOTAMEDI, B. HOSSEINI, H. MOHAMMADIAN, Z. MALAKI, F. GHAMARI, F. GHAFFARI (2002): Echinococcosis/hydatidosis in western Iran. Vet. Parasitol. 105, 161-171.

FINNEY, D. J. (1962): Probit analysis- a statistical treatment of the response curve. Cambridge University Press, Cambridge, pp 1-318.

GHOLAMI, S. H., B. RAHIMI-ESBOEI, M. A. EBRAHIMZADEH, M. POURHAJIBAGHER (2013): In vitro effect of Sambucus ebuluson scolices of hydatid cysts. Europ. Rev. Med. Pharmacol. Sci. 17, 1760-1765.

GOUDARZI, G. R., M. SAHARKHIZ, M. SATTARI, K. ZOMORODIAN (2011): Antibacterial activity and chemical composition of Ajowan (Carum copticum Benth. \& Hook) essential oil. J. Agric. Sci. Technol. 13, 203-208.

GUNDAMARAJU, R. (2013): Evaluation of anti-helminthic activity of Ferula foetida 'Hing- A natural Indian spice' aqueous extract. Asian Pac. J. Trop. Dis. 3, 189-191.

DOI: 10. 1016/S2222-1808(13)60038-9

HEMPHILL, A., J. MÜLLER (2009): Alveolar and cystic echinococcosis: towards novel chemotherapeutical treatment options. J. Helminthol. 83, 99-111.

DOI: 10. 1017/S0022149X0928936X

KARAOGLANOGLU, O. F., M. AKINCI, M. R. ULUKANLIGIL, H. C. METIN (2011): Hydatid cyst viability: the effect of scolicidal agents on the scolex in the daughter cyst. Turk. J. Medical Sci. 41, 1001-1006.

DOI: $10.3906 /$ sag-1010-1240

LARRIEU, E., M. T. COSTA, G. CANTONI, R. ALVAREZ, L. CAVAGION, J. L. LABANCHI, R. BIGATTI, D. ARAYA, E. HERRERO, E. ALVAREZ, S. MANCINI, PERLA, P. CABRERA (2001): Ovine Echinococcus granulosus transmission dynamics in the province of Rio Negro, Argentina, 1980-1999. Vet. Parasitol. 98, 263-272.

MAHENDRA, P., S. BISHT (2012): Ferula asafoetida: Traditional uses and pharmacological activity. Pharmacogn. Rev. 6, 141-146.

DOI: $10.4103 / 0973-7847.99948$
MAZZIO, E. A., K. F. SOLIMAN (2011): In vitro screening of tumoricidal properties of international medicinal herbs: part II. Phytother. Res. 24, 1813-1824.

DOI: $10.1002 /$ ptr. 2636

MOAZENI, M., M. J. SAHARKHIJ, A. A. HOSSEINI (2012): In vitro lethal effect of ajowan (Trachyspermum ammi L. ) essential oil on hydatid cyst protoscoleces. Vet. Para. 187, 203-208.

MOAZENI, M., S. BORJI, M. S. DARBANDI, M. J. SAHARKHIZ (2017): In vitro and in vivo antihydatid activity of a nano emulsion of Zataria multiflora essential oils. Res. Vet. Sci. 114, 308-312.

DOI: 10. 1016/j. rvsc. 2017. 06. 003

MOLLAZADEH, S., M. M. MATIN, M. IRANSHAHI, A. R. BAHRAMI, V. NESHATI, F. BEHNAM-RASSOULI (2010): The enhancement of vincristine cytotoxicity by combination with feselol. J. Asian Nat. Prod. Res. 12, 569575 .

DOI: 10. 1080/10286020. 2010. 485565

MORO, P., P. M. SCHANTZ (2009): Echinococcosis: a review. Int. J. Infect. Dis. 13, 125-133.

DOI: 10. 1016/j. ijid. 2008. 03. 037

NAGALAKSHMI, S., N. B. SHANKARACHARYA, J. P. NAIK, L. J. M. RAO (2000): Studies on chemical and technological aspects of ajowan (Trachyspermum ammi syn. Carum copticum) J. Food Sci. Technol. 37, 277-281.

NICOLAO, M. C., M. C. ELISSONDO, G. M. DENEGRI, A. B. GOYA, A. C. CUMINO (2014): In Vitro and in vivo effects of tamoxifen against larval stage Echinococcus granulosus. Antimicrob. Agents Chemother. 58, 51465154.

DOI: 10. 1128/AAC. 02113-13

PANDEY, S. K., S. UPADHYAY, A. K. TRIPATHI (2009): Insecticidal and repellent activities of thymol from essential seeds of Trachyspermum ammi (Linn) spargue seeds against Anopheles stephensi. Parasitol. Res. 105, 507-512.

DOI: $10.1007 / \mathrm{s} 00436-009-1429-6$

PENSEL, P. E., M. A. MAGGIORE, L. B. GENDE, M. J. EGUARAS, M. G. DENEGRI, M. C. ELISSONDO (2014): Efficacy of essential oils of Thymus vulgaris and Origanum vulgare on Echinococcus granulosus. Interdiscipl. Perspect Infect. Dis. 1, 12. DOI: $10.1155 / 2014 / 693289$

ROSTAMI, A., M. TAHERI, M. GHOLIZADEH, S. J. SEYYEDTABAEI, S. RAEGHI, S. FALLAHI (2016): Scolicidal effect of some herbs on Echinococcus granulosus protoscoleces: a systematic literature review. Herb. Med. J. $1,53-59$.

SAIKIA, M, P. J. HANDIQUE (2013): Antioxidant and antibacterial activity of leaf and bark extracts of seabuckthorn (Hippophae salicifolia D. Don) of North West India. Int. J. LifeSc. Bt. \& Pharm. Res. 2, 80-91. 
SHAHNAZI, M., A. AZADMEHR, R. LATIFI, R. HAJIAGHAEE, M. SARAEI, M. ALIPOUR (2016): In vitro protoscolicidal effects of various concentrations of Ziziphora tenuior L. extract at different exposure times. Avicenna J. Phytomed. 6, 376-382.

SMYTH, J. D., N. J. BARRETT (1980): Procedures for testing the viability of human hydatid cysts following surgical removal, especially after chemotherapy. Trans. R. Soc. Trop. Med. Hyg. 74, 649-652.
WALKER, M., J. F. ROSSIGNOL, P. TORGERSON, A. HEMPHILL (2004): In vitro effects of nitazoxanide on Echinococcus granulosus protoscoleces and metacestodes. J. Antimicrob. Chemother. 54, 609-616.

DOI: $10.1093 / \mathrm{jac} / \mathrm{dkh} 386$

Received: 4 October 2018

Accepted: 27 February 2020

MOUdGIL, A. D., P. MOUdGIL, D. SHARMA, P. S. DAUNDKAR, R. K. AGNIHOTRI: Procjena in vitro protoskolicidne učinkovitosti metanolnih biljnih ekstrakata na hidatidne ciste. Vet. arhiv 90, 197-204, 2020.

SAŽETAK

Cilj je istraživanja bila procjena protoskolicidnog potencijala metanolnih ekstrakata triju biljaka: Ferula asafoetida (sušena smola), Trachyspermum ammi (voće) i Hippophae salicifolia (lišće) u trima različitim koncentracijama (10, 20 i $30 \mathrm{mg} / \mathrm{mL}$ ) u 20, 40 i 60-minutnim pokusnim intervalima u odnosu na standardni alopatski lijek albendazol. In vitro vitalnost protoskoleksa procijenjena je metodom isključivanja eozina. Krivulja pomora i smrtonosne koncentracije za $50 \%\left(\mathrm{LC}_{50}\right)$ određena je iz regresijskih grafikona mortaliteta protoskoleksa u odnosu na log vrijednosti rastućih koncentracija biljnih ekstrakata tijekom 60-minutnog intervala. Pomor uzrokovan različitim ekstraktima u koncentracijama od 10 do $30 \mathrm{mg} / \mathrm{mL}$ varirao je od 29,54 do 97,76 \% s najvišim postotkom od 97,76, 97,30 i 81,91 \% u slučaju metanolnih ekstrakata $F$. asafoetida, T. ammi i $H$. salicifolia. Od svih primijenjenih ekstrakata najvišu protoskolicidnu aktivnost imala je $F$. asafoetida u koncentracijama od 20 i $30 \mathrm{mg} / \mathrm{mL}$ tijekom tretmana od 60 (97,16 \%) i 40/60 minuta (97,20 i 97,76\%), te je pokazala minimalnu vrijednost $\mathrm{LC}_{50}$ od 0,204, praćenu s T. ammi od 0,933. Usporedbom sa standardnim antiparazitikom albendazolom, metanolni ekstrakti biljaka F. asafoetida i T. ammi ostvarili su bolji ili slični protoskolicidni učinak.

Ključne riječi: hidatidoza; biljke; smrtonosna koncentracija; protoskolicidna aktivnost 